\title{
Margareta Ryberg (1946-2012): a personal tribute
}

\author{
Hans Ryberg • Lars Olof Björn • Britta Skagerfält • \\ Gunvor Björn
}

Received: 12 May 2012/Accepted: 18 May 2012/Published online: 6 June 2012

(C) Springer Science+Business Media B.V. 2012

\begin{abstract}
We pay tribute to the life and work of Margareta Ryberg (1946-2012). She was an expert on the different forms of protochlorophyll(ide), their protein partners, and their transformations in angiosperms; on the structural aspects, and the nature of prolamellar bodies, as well as on the localization of light-dependent NADPH:protochlorophyllide oxido-reductase. She was a great teacher, who also loved gardening and handicraft. But above all, she was a beloved wife, mother, grandmother, and friend who will be deeply missed.
\end{abstract}

Keywords Protochlorophyllide - Prolamellar body . NADPH:protochlorophyllide oxido-reductase

A beloved wife, mother and grandmother, and a very dear friend and colleague, has unexpectedly left us, much too early (see Fig. 1). Margareta Ryberg, née Kvist, was born

This tribute was invited and edited by Govindjee, Founding Historical Corner Editor of Photosynthesis Research.

H. Ryberg

Hovås Bräckaväg 36, 43654 Hovås, Sweden

e-mail: hansryberg43@gmail.com

\section{O. Björn ( $\square)$}

Department of Biology, Lund University, Biology Building A,

Sölvegatan 35, 22362 Lund, Sweden

e-mail: Lars_Olof.Bjorn@biol.lu.se

B. Skagerfält

Hembergavägen 59, 18773 Täby, Sweden

e-mail: britta.skagerfalt@gmail.com

G. Björn

Department of Biology, Lund University, Sölvegatan 35,

22362 Lund, Sweden

e-mail: gsbjorn@gmail.com

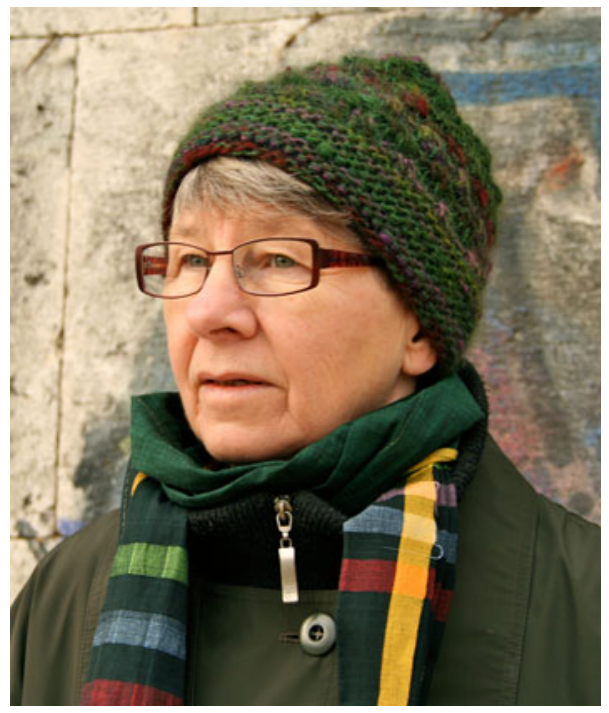

Fig. 1 Margareta Ryberg by the Tiber, Rome, January 2010. Photo by Britta Skagerfält, co-author of this Tribute, and daughter of Margareta

on April 14, 1946 in Göteborg, Sweden. After graduating from high school in 1966, Margareta continued her studies with zoology, botany, and chemistry at the University of Göteborg. During one of the first courses, Margareta met her husband to-be, Hans (co-author of this Tribute), and they married in 1969. Margareta and Hans continued studying botany in Göteborg and were both hired as teaching assistants before their postgraduate studies. Margareta defended her $\mathrm{PhD}$ thesis in Plant Physiology in 1982. Her thesis was under the supervision of Hemming Virgin and Christer Sundqvist. After her doctoral degree, she continued to work in the same department throughout her professional career. Margareta spent a few research periods abroad. In Kiel, Germany, she worked with Klaus 
Apel (now at the Boyce Thompson Institute in Ithaca, NY, USA) and with Katayoon (Katie) Dehesh (now at University of California at Davis, CA, USA; see Dehesh and Ryberg 1985; Ryberg and Dehesh 1986; Dehesh et al. 1986). Katie came to be like a sister to Margareta.

Over the years, Margareta was given an ever-greater responsibility for the teaching of plant physiology at the University of Göteborg. Devoted and demanding, she remained highly appreciated by her students.

In research, Margareta consistently followed a theme which had also occupied one of us (LOB) in the early days: the different forms of protochlorophyll(ide), their protein partners, and their transformations in angiosperms. Etioplasts from wheat were fractionated by differential and density gradient centrifugations, and the fractions analyzed by many different methods, in particular absorption, fluorescence, and circular dichroism spectrophotometry (Böddi et al. 1989, 1992). Eventually her studies became concerned with structural aspects and the nature of prolamellar bodies. Polyacrylamide electrophoresis, electron microscopy, liquid chromatography, mass spectroscopy, and immunolabeling were added to the methods in order to study the nature and role of the protein components and the localization and roles of light-dependent NADPH:protochlorophyllide oxidoreductases, PORs (Ryberg and Sundqvist 1982, 1988; Ryberg and Dehesh 1986). While POR concentration decreased in plastids during illumination, it remained constant in the cytoplasm (Dehesh et al. 1986). It was found that prolamellar bodies are formed not only in etioplasts, but also, during the night, in young chloroplasts of young developing leaves. Sixty-four unique proteins were identified in prolamellar bodies, catalyzing pigment synthesis and various photosynthetic reactions. One POR protein, POR A, was found to dominate the proteome of prolamellar bodies, and POR B was found for the first time in dark-grown wheat (Blomqvist et al. 2008). Margareta has over 60 publications on this topic in the Web of Science. There were no quick fixes, but always solid and well-documented science.

Margareta and Hans had two daughters, Britta and Karin, born in 1974 and in 1977, respectively.

Margareta was a keen gardener, as everyone visiting her home could experience, and she was also very much interested in the wilderness, which we are so fortunate to enjoy in abundance in Sweden. All sorts of handicraft also fascinated Margareta-among other things she travelled twice to China explicitly to study local techniques-and she was a driving force on the board of the local handicraft association. She was just as interested in woodworking as in textile techniques, and practiced both. As with all her interests in life she was keen to pass on to others what she knew, and frequently attended courses to learn and revive old, almost forgotten techniques. Another great interest that gave all of us much pleasure was her excellent cooking, often with ingredients from her garden and nature.

Margareta is no longer with us; she suffered a sudden and a very massive stroke, but in many ways she has helped others to continue their lives. In death she extended the most generous gift anyone can give. Her warm and kind heart still beats in another body. Someone else can take new and deeper breaths with Margareta's lungs. Her spirit lives on in her children and grandchildren. Our loss is great and we mourn that we can no longer share laughter, intense discussions, and crisp morning walks or coffee on the veranda.

Katayoon (Katie) Dehesh wrote:

I would like to add that Margareta made my world so much bigger, and my outlook to science so much more profound. She will always remain as my sister, friend and colleague.

We try to find comfort in the wise words attributed to Confucius and several later philosophers and writers: 'Do not weep because the glorious days are over, but rejoice that they have been.'

Acknowledgments We thank Klaus Apel (kha24@cornell.edu) and Katie Dehesh (kdehesh@ucdavis.edu) for reading this Tribute and for their contributions. We are grateful to Govindjee for his constant help in preparing this Tribute for Photosynthesis Research.

\section{References}

Blomqvist LA, Ryberg M, Sundqvist C (2008) Proteomic analysis of highly purified prolamellar bodies reveals their significance in chloroplast development. Photosynth Res 96:37-50

Böddi B, Lindsten A, Ryberg M et al (1989) On the aggregation states of protochlorophyllide and its protein complexes in wheat etioplasts. Physiol Plant 76:135-143

Böddi B, Ryberg M, Sundqvist C (1992) Identification of 4 universal protochlorophyllide forms in dark-grown leaves by analyses of the 77-K fluorescence emission-spectra. J Photochem Photobiol B 12:389-401

Dehesh K, Ryberg M (1985) The NADPH-protochlorophyllide oxidoreductase is the major protein constituent of prolamellar bodies in wheat (Triticum aestivum L.). Planta 164:396-399

Dehesh K, van Cleve B, Ryberg M, Apel K (1986) Light-induced changes in the distribution of the $36000-\mathrm{M}_{\mathrm{r}}$ polypeptide of NADPH-protochlorophyllide oxidoreductase within different cellular compartments of barley (Hordeum vulgare L.). Planta 169:172-183

Ryberg M, Dehesh K (1986) Localization of NADPH-protochlorophyllide oxidoreductase in dark-grown wheat (Triticum aestivum) by immunoelectron microscopy before and after transformation of the prolamellar bodies. Physiol Plant 66:616-624

Ryberg M, Sundqvist C (1982) Characterization of prolamellar bodies and prothylakoids fractionated from wheat etioplasts. Physiol Plant 56:125-132

Ryberg M, Sundqvist C (1988) The regular ultrastructure of isolated prolamellar bodies depends on the presence of membrane-bound NADPH-protochlorophyllide oxidoreductase. Physiol Plant 73: 218-226 